\title{
Curbing the lifestyle disease pandemic: making progress on an interdisciplinary research agenda for law and policy interventions
}

\author{
Brigit Toebes ${ }^{1,2^{*}}$ (D), Marlies Hesselman ${ }^{1,2}$, Jitse P. van Dijk ${ }^{3}$ and Joost Herman ${ }^{4}$
}

\begin{abstract}
By 2030, noncommunicable diseases (NCDs) will be the leading cause of death in every region in the world. While law and policy have an important role to play in curbing this pandemic, our current understanding of how they can most effectively be used is still limited. This contribution identifies a number of gaps in current research and insists on an interdisciplinary research agenda between law, health science and international relations aimed at designing concrete proposals for laws and policies to curb the NCD pandemic, both globally and domestically.
\end{abstract}

Keywords: Noncommunicable diseases, Interdisciplinary research agenda, Law and policy

\section{Background}

In 2012, 38 million people died from noncommunicable diseases (NCDs), accounting for $68 \%$ of total deaths globally $[1,2]$. NCDs include cardiovascular diseases, cancer, chronic respiratory diseases and diabetes. Importantly, NCDs are not merely a problem of highincome countries; their impact is universal. Around 28 million NCD-related deaths already occur in low and middle-income countries, and by 2030, NCDs will be the leading cause of death in every part of the world [2].

The scale and universality of the problem make NCDs a pandemic phenomenon that requires a powerful international response. In this response, prevention is key, because much of the global NCD burden (40\%) is linked to four "modifiable behavioral risk factors" that affect many countries: tobacco use, unhealthy diets, physical inactivity and harmful use of alcohol (Fig. 1; and per 2). Moreover, the rapid global spread of these risk factors is at least partially assisted by the globalization of the

\footnotetext{
*Correspondence: b.c.a.toebes@rug.nl

${ }^{1}$ Global Health Law Groningen Research Centre, Department of International Law, Faculty of Law, University of Groningen, Oude Kijk in 't Jatstraat 26, 9712 EK Groningen, the Netherlands

${ }^{2}$ Department of International Law, Faculty of Law, University of Groningen, Oude Kijk in 't Jatstraat 26, 9712 EK Groningen, the Netherlands

Full list of author information is available at the end of the article
}

production, marketing and sales of harmful foods, beverages, alcohol, and tobacco products. Therefore, a strong, concerted international response is essential [3].

In recent years there has been a sizable international political commitment to curbing NCDs. In 2015, the United Nations General Assembly pledged in its Sustainable Development Goals to reduce NCDs by one-third by 2030. In parallel, the World Health Organization (WHO) adopted a set of nine voluntary targets on NCDs to be attained by 2025 [4]. This '2013-2020 WHO NCD Action Plan' has been heralded as a paradigm shift for the response to NCDs, as it is the first international road map with a menu of policy options for States and other institutions to follow to achieve a substantial reduction in NCDs. Among the policy options mentioned are raising taxes on sugar, tobacco or alcohol, introducing packaging and labeling requirements, banning or limiting advertisements, and regulating the availability of products, or products' ingredients [4].

Researchers from various disciplinary angles have engaged with NCDs and have made a meaningful contribution to the development of effective NCD laws and policies [5-8]. However, we observe that this type of research does not always receive the support and outreach it deserves. Specifically, many more efforts and resources should be allocated to interdisciplinary research 


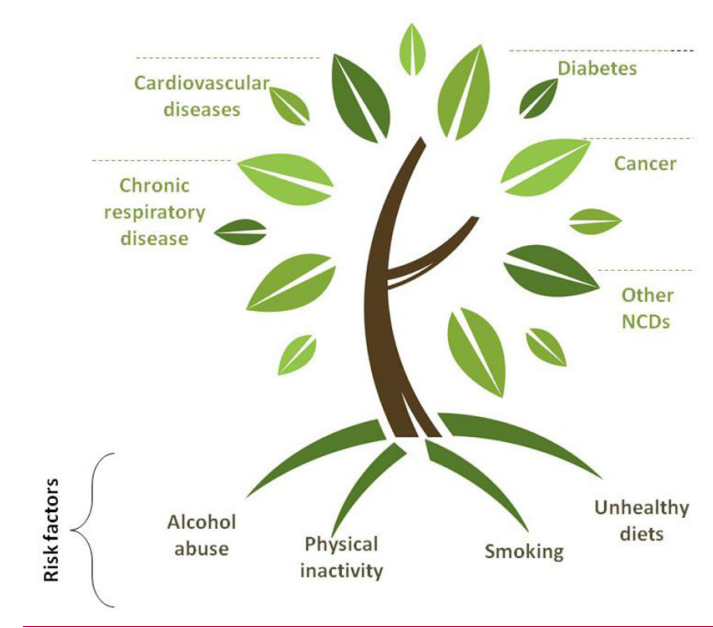

Fig. 1 Modifiable Behavioural Risk Factors (Regional Office for the Eastern Mediterranean, WHO). Reprinted with permission from the WHO

endeavours, which, given the magnitude and complexity of the problem, deserve more attention.

While law and policy interventions have proven successful in curbing NCD incidence already, we need to learn more about the success factors that can be attributed to recent domestic and international instruments. To achieve this goal, we argue in favour of a truly integrated research agenda spanning health science, domestic and international legal scholarship, and international relations theory. In practice, this means that (traditional) law and policy-oriented NCD-research needs to build more on health science and international relations research, but also that health science can generate insights on the success of policy interventions. This is further explained below. In addition, domestic and international policy makers should better understand the important role of legal arrangements, while lawmakers can learn from domestic and international policy realities and other challenges to which legal interventions need to respond.

The overall aim of our proposed integrated research agenda is to develop a comprehensive toolbox that can guide law and policy making, and assists identifying 'good practice' laws and policies for domestic governments to adopt [9]. This type of research needs to be developed in particular in Low and Middle Income Countries (LMICs), where little research on NCDs is carried out, in particular when it comes to evaluating good practice interventions in a local context [9].

\section{Linking health science with law and policy research}

Domestically, there is increasing evidence that taxes on sugar sweetened beverages result in reduced consumption of these beverages, and that subsidies for fresh fruits and vegetables can increase fruit and vegetable consumption [10]. Moreover, bans on fast-food advertisements targeted at children have been linked to low childhood obesity rates in Canada [3]. Internationally, the Framework Convention on Tobacco Control represents a unique, binding treaty that has encouraged many countries to adjust their tobacco laws and policies [11].

At the same time, knowledge about the various regulatory options available to lawmakers and policymakers can be greatly improved [9]. Evidence so far suggests that modifiable risk factors can be addressed in a variety of ways, including targeting individual behavior, producers and sales points, each of which have specific advantages and disadvantages [12]. Laws can target consumers by creating incentives and disincentives that directly shape consumer behavior (e.g. taxes and subsidies), or by facilitating behavioral change (e.g. nutritional information). Yet, legislators can also regulate the industry or sales points, for example, by restricting unhealthy food promotion, restricting the sale of products (general bans, age-requirements), or by posing requirements on ingredients or packaging [13].

To identify effective law and policy options, in particular 'best practices', coordination between health science and law is crucial. Evidence of current patterns of NCDs, and interventions related to them, creates insights into which laws and policies can best be put into place. It also reveals how the implementation of laws and policies is succeeding. In respect of evidence, the estimate that in Europe obesity accounts for about $65-80 \%$ of new cases of Type 2 Diabetes is an important signal to legislators to reflect on the need to regulate risk factors such as unhealthy diets, which may be achieved by more effective regulation of certain foods [14]. At the same time, there is currently a lack of comprehensive data linking the incidence of NCDs to (certain types of) legal interventions. To design an adequate legal response, such data need to be specified per NCD. It is also important to generate data on the effects of adjusting modifiable determinants on health outcomes. For instance, knowledge about the health benefits of reduced salt intake (as a modifiable determinant) assists deciding on which legal and policy measures to take to help reduce the incidence of cardiovascular disease. Examples of measures to be taken in this area include setting appropriate standards for ingredients (for certain products), e.g. the levels of salt, requiring improved labeling, imposing taxes on certain products, and providing guidelines on cooking and salt intake. To choose the right policy option, a full investigation of the various specific legal and policy interventions that are possible, as well as those already undertaken in various domestic legal systems, needs to be carried out. Knowledge of these aspects is growing, but as yet incomplete $[11,12]$.

Despite overwhelming evidence of the scale of the NCD pandemic, and the importance and possibilities of 
curbing NCDs through prevention, we are aware that attempting to change lifestyle raises the difficult question as to whether and how national and international authorities should and can attempt to influence the behavioral and consumption patterns of individuals directly through regulation [15]. First, due to an emphasis on autonomy and personal responsibility, in particular in high- income countries, there is resistance in society to the implementation of such preventive measures [16].

Second, there is evidence that nudging, through regulation alone, may be insufficient because there are important underlying social determinants of health. For example, poverty, poor family relations, unemployment, and a lack of adequate education may increase engagement in certain risk factors $[5,6]$. Successful policy interventions thus need to be embedded in multisectoral approaches spanning various policy sectors. From a research perspective, it requires a willingness and ability on the part of researchers to engage with scholars and insights from other disciplines [7].

Lastly, the practical and social role of companies should not be under-estimated. They heavily control essential aspects such as marketing, a product's ingredients and presentation, and the availability of alternative products. These are important factors that influence people's free choice which cannot be ignored. Moreover, while marketing bans or sales points restrictions may offer powerful tools to counter some of these forces, typically, tobacco, alcohol and food and beverages' companies also have large budgets for lobbying and influencing markets and policy-makers in profound, if not subversive, ways. This type of influence may also have to be reigned in, nationally and internationally.

Despite the fact that NCDs pose the largest threat to future global health, they remain an under-emphasized area of inter-disciplinary research [8]. We argue that more research should be conducted aimed at filling the above-mentioned gaps and with the ultimate aim of identifying the best law and policy interventions [8]. To gain a full perspective, an interaction between the legal discipline and health science is key.

\section{Promoting social and legal change globally}

Another under-researched dimension of NCDs concerns the question of how social and legal change can be brought about at both international and domestic levels. International relations' research can give a crucial insight into the political processes required for new effective NCD laws and policies to be adopted. A close interaction between law and political science is required to study these mechanisms.

International laws and guidelines are essential for global agenda-setting in relation to NCDs and to ensure a comprehensive international response to the rising $\mathrm{NCD}$ pandemic. They present an important driving force for national authorities to prioritize certain health concerns and arrive at better regulation. So far the only legally binding international instrument that addresses a behavioral risk factor is the WHO's Framework Convention on Tobacco Control (FCTC). This influential treaty, which was adopted in 2003 and is currently ratified by 179 countries, has led to a tightening of many domestic tobacco laws and to several domestic court cases addressing the harmful effects of tobacco [11]. There have been many calls over the last decade to adopt more instruments addressing the other risk factors [17]. The feasibility of new instruments should be explored further and important lessons regarding the form and content of such instruments can be drawn from the FCTC [18].

An important related question is whether new international standards should be pursued through treatymaking, or whether "soft-law" instruments in the form of Guidelines, Standards, Codes of Conduct or Action Plans can be equally effective in soliciting desired change and action. There is now evidence suggesting that more flexible, informal instruments might be equally, if not more effective in guiding States and other actor's behavior, as long as the instrument is sufficiently precise and instructive, and has come about through a broad (multi-)stakeholder effort [19]. On the other hand, in terms of enforceability, binding international treaties can be very valuable instruments domestically, in domestic court proceedings and by legally requiring States to strengthen enforceable domestic laws. There is clearly a further research agenda here.

It is also important to understand how new international legal norms may emerge - or even can be actively pursued, framed, diffused, put into effect, and ultimately implemented. Models that explain 'international norm dynamics' in social constructivist international relations theory provide useful insights into how key domestic and international actors, including so-called "norm entrepreneurs", interact with each other in relevant global networks and organizations such as the WHO. They explain how a sufficient momentum for the adoption of new instruments may come about, or not [20,21]. In addition, such theories can explain the dynamics of "compliance", "socialization" or "internalization" of norms, both nationally and internationally, which ultimately lead to law and policy action domestically [20,22].

Finally, international relations theory suggests that any process of norm creation needs to start with agendasetting and persuasion, or framing efforts by one or more dedicated "norm entrepreneurs" with (access to) sufficiently strong organizational platforms to spread their messages $[20,21]$. One practical problem here is that the current international NCD law and policy agenda - and the NCD movement - is still nascent, and 
to some extent dispersed. There are at least four different NCDs that need to be addressed, and these are attributed to at least four complicated (and intersecting) risk factors. They are also covered by different diseasespecific organizations (cancer foundations, diabetes foundations, etc.) [3]. A key question here may be to identify what leads to successful norm emergence, and how the efforts on various NCD agenda's and related risk factors (e.g. alcohol, tobacco, sugar, salt) compare or may be combined (or not).

In pursuing effective global law and policy responses to NCDs, it will be crucial not only to understand health science and policy options on NCDs and risk factors, but also to understand the various critical factors that determine the success or failure of global health law-making efforts. Such critical factors can relate to the presence of successful norm entrepreneurs, or to understanding better how non-binding WHO instruments can inform and strengthen domestic responses to NCDs, in particular, in comparison to binding instruments such as the FCTC.

\section{Conclusions}

The role of law and policy in regulating modifiable behavioral risk factors, including tobacco use, alcohol, unhealthy diets and low physical activity, has gained increased attention in international and domestic NCD debates. This article highlights that there is considerable evidence for successful international and domestic legal interventions, but also identifies salient knowledge gaps on the exact role of and options for suitable law and policy responses. Therefore, and in order to meet the ambitious goals on NCD reduction now set out in the Sustainable Development Goals, this article identifies key questions for a bold interdisciplinary research agenda which requires researchers in various fields to work more closely together.

\section{Abbreviations}

FCTC: Framework Convention on Tobacco Control; NCDs: Noncommunicable diseases; WHO: World Health Organization

\section{Acknowledgments}

Mike Gould provided professional writing services as a language editor to an earlier version of this article. He has given permission to acknowledge him as an editor.

\section{Funding}

BT receives funding from the Dutch Cancer Society (KWF) for legal research in the more narrow are of tobacco tobacco control. This organization did not play a role in the design of the study and collection, analysis, and interpretation of data, nor in writing the manuscript.

\section{Availability of data and materials}

No original data were used; all data used for this manuscript were obtained through library and internet search.

\section{Authors' contributions}

BT developed the concept of the manuscript and developed the first draft in collaboration with $\mathrm{MH}$; JD contributed to all the following drafts; JH delivered feedback on the last two drafts. All authors read and approved the final manuscript.

\section{Authors' information}

$\mathrm{BT}$ is a scholar in international health and human rights law; $\mathrm{MH}$ is a public international law, human rights, and international relations scholar; JD is a scholar in community medicine; $\mathrm{JH}$ is a scholar in international relations.

Ethics approval and consent to participate

This manuscript does not report on a study involving human participants, human data or human tissue.

\section{Consent for publication}

This manuscript does not contain any individual person's data.

Competing interests

The authors declare they have no competing interests.

\section{Publisher's Note}

Springer Nature remains neutral with regard to jurisdictional claims in published maps and institutional affiliations.

\section{Author details}

${ }^{1}$ Global Health Law Groningen Research Centre, Department of International Law, Faculty of Law, University of Groningen, Oude Kijk in 't Jatstraat 26, 9712 EK Groningen, the Netherlands. ${ }^{2}$ Department of International Law, Faculty of Law, University of Groningen, Oude Kijk in 't Jatstraat 26, 9712 EK Groningen, the Netherlands. ${ }^{3}$ Department of Community and Occupational Medicine, University Medical Center Groningen, University of Groningen, Ant. Deusinglaan 1, 9713 AV Groningen, the Netherlands. ${ }^{4}$ Faculty of Arts, Oude Kijk in 't Jatstraat 26, 9712 EK Groningen, The Netherlands.

Received: 11 May 2017 Accepted: 4 September 2017

Published online: 18 September 2017

\section{References}

1. WHO: Noncommunicable Diseases. http://www.who.int/mediacentre/ factsheets/fs355/en/ (2005). Accessed 6 Mar 2017.

2. WHO: Global Status Report on Noncommunicable Diseases 2014. http:// www.who.int/nmh/publications/ncd-status-report-2014/en/ (2014). Accessed 6 Mar 2017.

3. Gostin LO. Global Health law. Harvard: Harvard University Press; 2014.

4. World Health Assembly: Global Action Plan for the Prevention and Control of Noncommunicable Diseases, 2013-2020. http://apps.who.int/iris/ bitstream/10665/94384/1/9789241506236_eng.pdf (27 May 2013). Accessed 6 Mar 2017

5. Stringhini S, et al. Socioeconomic status and the $25 \times 25$ risk factors as determinants of premature mortality: a multicohort study and meta-analysis of 1.7 Million men and women. Lancet. 2017;389:1229.

6. Di Cesare $\mathrm{M}$, et al. Non-communicable diseases 3 - inequalities in noncommunicable diseases and effective responses. Lancet. 2016;381:585.

7. Garde A. The "obesity risk": for an effective use of law to prevent noncommunicable diseases. Eur J Risk Regul. 2017;8:77.

8. Horton R. Non-communicable diseases: 2015-2025. Lancet. 2016;381:509.

9. Allen L. Noncommunicable disease research. Int J Non-Commun Dis. 2016;1:131.

10. WHO: Fiscal Policies for Diet and Prevention on Noncommunicable Diseases. http://apps.who.int/iris/bitstream/10665/250131/1/9789241511247eng.pdf?ua=1 (5-6 May 2016). Accessed 6 Mar 2017.

11. Taylor AL, Parentho EW, Schmidt LA. The increasing weight of regulation: countries combat the global obesity pandemic. Indiana Law J. 2015:90:257.

12. Mensah GA. Law as a tool for preventing chronic diseases: expanding the Spectrum of effective public health strategies - preventing chronic disease. Public Health Res Pract Policy. 2004;1:1.

13. Mackay S. Legislative solutions to unhealthy eating and obesity in Australia. Public Health. 2011;125:896.

14. WHO Europe: Noncommunicable Diseases, Diabetes. http://www.euro.who. int/en/health-topics/noncommunicable-diseases/diabetes/data-and-statistics. Accessed 6 Mar 2017.

15. Sunstein CR. Why nudge?, the politics of libertarian paternalism. New Haven \& London: Yale University Press; 2014

16. Magnusson RG, Patterson D. The role of law and governance reform in the global response to non-communicable diseases. Glob Health. 2014;10:1. 
17. Consumers International, World Obesity Foundation, Recommendations for a Global Convention on Unhealthy Diets. http://www. consumersinternational.org/media/2211/recommendations-for-aconvention-on-healthy-diets-low-res-for-web.pdf. Accessed 24 July 2017.

18. Hesselman M, Toebes B. Adopting new international health instruments what can we learn from the FCTC? Comment on "the legal strength of international health instruments - what it brings to Global Health governance?". Int J Health Policy Manag. 2017;6(x):1-4.

19. Pauwelyn J, Wessel R, Wouters J. When structures become shackles: stagnation and dynamics in international lawmaking. Eur J Int Law. 2014;25:733.

20. Finnemore $M$, Sikkink K. International norm dynamics and political change. Int Organ. 1998;54:887.

21. Segerlund L. Making corporate social responsibility a global concern: norm construction in a global world. Farnham: Ashgate; 2010.

22. Risse T, Sikkink K, Ropp S, editors. The persistent power of human rights: international norms and domestic change. Cambridge: CUP; 1999.

Submit your next manuscript to BioMed Central and we will help you at every step:

- We accept pre-submission inquiries

- Our selector tool helps you to find the most relevant journal

- We provide round the clock customer support

- Convenient online submission

- Thorough peer review

- Inclusion in PubMed and all major indexing services

- Maximum visibility for your research

Submit your manuscript at www.biomedcentral.com/submit
Biomed Central 